\title{
Юлія Браӥлко*
}

(iD) https://orcid.org/0000-0001-5203-7479

\section{МОДЕЛЮВАННЯ ЛІНГВОПОЕТИЧНОГО КОДУ ТОПОНІМА ВАРШАВА В УКРАЇНСЬКОМУ ДИСКУРСІ}

\section{MODELING OF THE LINGUOPOETIC CODE OF THE TOPONYM WARSAW IN THE UKRAINIAN DISCOURSE}

Ключові слова: поетичний дискурс, онім, топонім, ойконім, хоронім, Варшава

Keywords: poetic discourse, onym, toponym, oikonym, choronym, Warsaw

\begin{abstract}
Анотація
У статті наведено результати аналізу лінгвопоетичного коду топоніма Варшава, який представляє «чужу» культуру в українському дискурсі XVIII-XXI століть. Моделювання такого коду зосереджене передусім в історично-подієвій площині. Автор стверджує, що це зумовлене територіальною близькістю, спільним минулим обох країн, політичним значенням Польщі для України. Письменники актуалізують здебільшого ту екстралінгвальну інформацію, що стосується мілітарної тематики. Продуктивними $є$ надання аналізованій власній назві ознак хороніма з одночасною актуалізацією таких значень, як «імперськість», «поневоленість» або «європейськість», застосування онімної взаємодії (топонімно-топонімної, топонімно-антропонімної). Значення «столиця» увиразнюють контекстуальні лексеми державність, держава, ойконімно-хоронімна пара Варшава - Річ Посполита. Топонім Варшава є також маркером «чужого» простору у відповідній бінарній опозиції, тоді як маркером «свого» простору стає, усупереч очікуванням, не корелятивний ойконім Київ, а хоронім Україна. Обмежено реалізовано фоновий потенціал ойконіма, пов'язаний із семантикою столиці, топосом міста. Через установлення топонімно-теонімної кореляції відбувається поетична сакралізація аналізованого оніма. Загалом інформаційне поле власної назви Варшава в українському поетичному дискурсі має асиметричний вияв із домінуванням історичного та помітністю соціокультурного сегмента.
\end{abstract}

* Полтавський національний педагогічний університет ім. В.Г. Короленка, психолого-педагогічний факультет, кафедра філологічних дисциплін і методик їх викладання, вул. Остроградського, 2, 36000, Полтава, Україна; e-mail: santie@ukr.net 


\begin{abstract}
This article offers an analysis of the linguopoetic code of the toponym Warsaw, which represents a "foreign" culture in Ukrainian discourse of the 18th-21st centuries. The modelling of such a code is primarily focused on the historical-event plane. The author states that this is due to Poland's territorial proximity and the political significance of Poland for Ukraine, together with the common past of both countries. The writers focus on updating extra lingual information related to military issues. It is productive to assign an analyzed proper name the features of the choronym with the simultaneous actualization of such meanings as "imperialism", "slavery" or "Europeanness"; the use of onymous interaction (toponymic-toponymic, toponymic-anthroponymic). The meaning of "capital" is expressed by the contextual lexemes statehood, state, and oikonymic-choronymic pair Warsaw - Rzeczpospolita. The toponym Warsaw also acts as a marker of "foreign" space in the corresponding binary opposition, while the "own" space becomes, contrary to expectations, not the correlative oikonym Kyiv but the choronym Ukraine. The background potential of the oikonym related to the semantics of the capital, the topos of the city, is limited. Due to the establishment of toponymic-theonymic correlation, there is a poetic sacralization of the analyzed onym. The information field of the toponym Warsaw has, in general, an asymmetric manifestation in Ukrainian poetic discourse. This is with the dominance of the historical and the visibility of the socio-cultural segment.
\end{abstract}

Серед численних ономастичних студій проблемам функціювання в поетичних текстах топонімів, що позначають «чужий» простір, приділено небагато уваги попри те, що їхня художня інтерпретація виходить за утрадиційнені локативні рамки, віддзеркалюючи авторське трактування історії, зв'язок національної культури зі світовою тощо. «Унікальність топонімів, як культурних знаків, полягає в їхній здатності формувати образ, поглиблюючи світобачення, світорозуміння, моральні, етичні та естетичні засади, - зазначає М. Доценко. - Отже, топоніми - це своєрідні “пам'ятники”, “музеї”, “дзеркала” історії та культури народу» [Доценко, 2016, с. 20], «маркери, які акумулюють важливу національно-культурну та історичну інформацію, пов'язану з життям певного етносу» [Мороз, 2011, с. 49]. Вивчення «чужих» топонімів у художньому тексті вможливлює ідентифікування того їхнього коду, який перебуває за рамками «ментального свого», оскільки він створений представниками іншої культури й відображає поетичну картину світу іншого етносу. 3 огляду на це тема нашого дослідження видається цікавою та актуальною для літературної ономастики.

Функції топоніма Варшава як одного з експлікаторів іноземних локусів в українських фольклорно-пісенних текстах принагідно вивчали М. Торчинський [2009], Н. Данилюк [2011], Н. Дубина [2000]. Поодинокі згадки про виражальний потенціал цього ойконіма знаходимо в працях М. Мельник [1999, с. 13, 15], І. Корнієнко, О. Єфімовської [2016, с. 138-139], Т. Можарової [2008, c. 185], О. Тєлєжкіної [2012, с. 432, 434], присвячених аналізові топонімікону/ ономастикону творів Л. Костенко, І. Драча, Д. Павличка. Р. Лейбов зробив удалу спробу на матеріалі російської поезії кінця XVIII - I половини XIX ст. 
встановити семантичні відношення астіоніма Варшава в римованій позиції, обгрунтувавши вибір цієї власної назви її тісним зв'язком із тогочасною політикою й національною міфологією [Лейбов, 2012, с. 188].

Мета статті - проаналізувати особливості лінгвопоетичного коду топоніма Варшава як репрезентанта «чужої» культури в українському поетичному дискурсі XVIII-XXI століть.

Власна назва Варшава є периферійною в онімному просторі української поезії, тоді як у польському поетичному ономастиконі вона є однією 3 основних континуант, зважаючи на свою ментальну вагомість (див., наприклад [Szelążek, 1918]). Водночас функційна сфера ойконіма Варшава в українському поетичному дискурсі сягає кількох століть: згадаймо «Піснь мандрованого ляха з Варшави» з рукописного пісенника Івана Пашковського середини XVIII ст. (Да йшов лямок із Варшави, / На нім бути, сукні шарі (автор невід.)), «Пісню про Варшаву», записану, за свідченням І. Франка, у 80-х роках XVIII ст. в Жидачівському та Калуському повітах (Oй чи чував хто о ляховській славі / Коли доступили до міста Варшави? (нар. тв.) [Франко, 1910, с. 48-49]).

На думку дослідників, топонім Варшава в українських фольклорних піснях необов'язково буде значеннєво містким, його, наприклад, «з легкістю можна замінити на іншу польську назву» [Дубина, 2000]. I. Франко доводить, що в згаданій вище пісні Варшава «нї при чім і заступила в нїй місце первісного иншого міста - Станїславова» [Франко, 1910, с. 50-51]. У такому разі можемо, вочевидь, говорити лише про певне указання на час появи твору - у період перебування частини українських земель під владою Речі Посполитої/Польщі.

За нашими спостереженнями, топонім Варшава в українських фольклорно-пісенних текстах часто використано з метою надання ваговитості певним подіям/особам: Заріж, заріж, господине, / індика, індика, / щоб нам була із Варшави / музика, музика; Вже ж бо ми пшениченьку дожали, / Найми нам музиченьки з Варшави [КОП, с. 259]; Наш хазяїн в дорозі, / Наняв музики в Острозі, / А цимибали в Варшаві, / Щоб мої женчики гуляли [ІП, с. 468]. Досить продуктивними є згадки про історичні події, зокрема про козацькі походи, повстання та їхніх ватажків: <..> Бог знає, бог відає, де мій милий ночує: / Чи він у обозі, чи в далекій дорозі, / Чи з паном, чи з гетьманом у Варшаві на залозі [СПП, с. 50]; Та поїдем у чистеє поле, гей, гей, у Варшаву, / Та наберем червоной китайки, гей, гей, та на славу [СПП, с. 46]; Та й повезли ж у Варшаву / Павлюка й Сулиму / Та й на тяжку муку-кару, / Всім ляхам на диво [УНДІП, с. 86]; Били турка денно, нічно / I храбро ступали, / А в середу пораненьку / 3 Кубані рушали, / А восьмої неділеньки / У Варшаві стали [УНДІП, с. 141]. 
М. Торчинський зазначає, що

макроойконіми (назви значних поселень) часто виступають символами певних територій, при цьому насамперед реєструються назви столиць сусідніх держав, принаймні у фольклорі: Гнали, гнали, не догнали, Й у Варшаві- там застали <...> [Торчинський, 2009, с. 43-44].

Зауважимо, що цей прийом часто застосовують і в авторській поезії, надаючи аналізованому ойконімові макротопонімної (хоронімної) семантики завдяки поєднанню метонімії (столиця $\rightarrow$ держава) та (за поодинокими винятками) антропоморфної метафори з одночасною актуалізацією таких значень:

- «імперськість»: Так от як кров свою лили / Батьки за Москву і Варшаву, / I вам, синам, передали / Свої кайдани, свою славу! [Шевченко, с. 352]; Ой, нехай же кобзи грають, / Нехай дзвонить слава, / Нехай чують нас $i$ знають / I Москва, й Варшава! [Куліш 2, с. 179]; Хай згинуть і Москва, й Варшава, / і німиі, й кожний їх слуга! [Бабій, с. 123]; Наша воля не прийшла із Відня, / Із Москви й Варшави не прийшла. / 3 Хортиці вона, печаль всесвітня, / Кров і піт з козацького чола [Павличко 2, с. 46];

- «ворог», «загарбник»: <...> знов наша Україна / Під Польщею буде, / I заціпить нашу волю / Гидкая Варшава... [Руданський 2, с. 75]; Коли душили нашу мову / Варшава, Відень і Москва, / Ми з праху поставали знову, / Снували і плели основу / Свого духовного єства; Аркан летить з Бахчисараю, / Петлю з Варшави кинув лях, / А з Півночі, мій рідний краю, / Боярин їде в соболях [Павличко 3, с. 40];

- «поневоленість»: Неволю Праги і Варшави / Радянські воїни змели <...> [Рильський, с. 55]; Варшава, Токіо і Рим / Повстань щуе гасла пронесуть [Усенко, с. 43]; <...> Піддались під більшовицькі стопи / Будапешт, Берлін, Варшава, Прага, / Та не піддались Березови [Павличко 1, с. 374].

Продуктивною $є$ й метонімізація ойконім $\rightarrow$ частина світу, унаслідок якої в поетичному контексті власна назва Варшава реалізує потенційне значення «європейськість»: Молиться за тебе [білоруський прапор] Україна, / Ждуть тебе Варшава і Париж...; Нас не ковтне непам'яті безодня, / Згадає Рим, Варшава і Париж - / Їх боронитиме Небесна Сотня, / Як людськості святої дивовиж. / Ми полягли на київськім Майдані, / Вже всоте зупиняючи орду [Павличко 2, с. 26]; Дитинко, ми наслідки цүих револющій, / поглянь, як нам світить зогнила Варшава. / Бо сонце щзоночі тіка до Свропи, / бо привид страху щуе блудить тілом [Жадан, с. 4].

Проаналізований мовний матеріал свідчить, що така метонімізація стає можливою завдяки топонімній (передусім ойконімній) взаємодії, яка водночас працює на посилення оцінної конотованості. Аксіологія власної назви 
Варшава, як й інших компонентів наведених вище топонімних рядів, у хоронімному поетичному витлумаченні прямо корелює з актуалізацією хронологійної інформації оніма: минуле ↔ пейоративне забарвлення (контрастивні значення «імперськість» (передусім експлікована в онімній парі Варшава - Москва), «ворог», «загарбник» та «поневоленість»), теперішнє ↔ позитивне (значення «європейськість» як вияв цивілізаційного орієнтиру українців, насамперед оприявнене онімною парою Варшава - Париж). Додамо, що зв'язок ойконімів Варшава й Москва може бути встановлено і з метою локалізації певної території та відсилання до історичних подій. Ця процедура $є$ індиферентною щодо метонімізації столиця $\rightarrow$ держава: Ген від Москви аж до Варшави / зачервоніли жупани, / козацтво «здобуває слави», / спис і нагайки скрізь пани [Українка, с. 113]; Сонце сліпне оком благим / У посмугованім небі іржавім - / Криваво палають земні сніги / Від Москви - / до Варшави [Самійленко, с. 130].

Виконання назвами столиць держав хоронімної функції є примітною особливістю не лише українського дискурсу [Ларина, 2014, с. 235; Милькевич, 2017, с. 148]. Російська дослідниця О. Мількевич пояснює активне застосування такої метонімічної моделі трьома когнітивними принципами: а) конкретне над абстрактним (конкретне місто чіткіше сприймає людська свідомість, ніж абстрактну країну); б) домінантне над недомінантним (столиця є домінантним елементом стосовно інших міст країни); в) центральне над периферійним (столиця $є$ центральним елементом країни) [Милькевич, 2017, с. 148].

Одне 3 активних в узуальному вжитку назви Варшава значення столиці виявляє ознаки периферійності в українському поетичному дискурсі. Його безпосередньо експлікують лише Д. Павличко ( $A$ може, їдуть до Варшави / Княжата ниці / На балювання та забави / В чужій столищі?; У тім'я дзьобали його орли / 3 Варшави, з Відня, з ияарської столиці [Павличко 4, с. 52] та Л. Костенко (Варшаво < .. > / I знову - столиия! [Костенко 2, с. 54], а інші письменники - через асоціативні зв'язки, актуалізовані, наприклад, назвою центрального органу польської влади: Був славетний колись каштелян. / Він гучної зажив отам слави, / Залишив ї̈ частку й синам, / Бо у сеймі, у самій Варшаві / Говорив гостре слово панам [Масенко, с. 355]; I коли делегації з Варшави / У Вінничі подарували / Незвичайне зображення / Івашкевича, / То навіть старійшина державного / сейму / Старий совізджал / Юзеф Озга-Міхальський / Засвідчив при всіх дивовижну / подібність / Пана Ярослава до портрета / I портрета до пана Ярослава [Лубківський, с. 125].

Значення «столиця» увиразнюють контекстуальні лексеми державність, держава, ойконімно-хоронімна пара Варшава - Річ Посполита, як-от: Варшава державністю гордо повита, / В Свропі, як розвидень, - Річ Посполита [Павличко 1, с. 223]; В порох збита, кров'ю злита, / під мазурку, під веселу / Річ 
потужна Посполита / оксамити знову стеле. / Хай з туману сонце гляне, / як гариюють, як таниюють / у Варшаві знов улани <..> [Клен, с. 308]. Важлива роль в описуваному механізмі належить і фонетичним засобам, зокрема римі, позаяк

висування власної назви в римовану позицію закріплює не лише лексему, але й іiі зв'язки з римованими одиницями, що в просторі ліричного тексту позначає створення стійкого тематико-сюжетного зв’язку між словами, що постають як повторювані співзвуччя [Лейбов, 2012, с. 187].

Застосування цього засобу для актуалізації значення столиці спостерігаємо в Д. Павличка: Бундючні втікачі з Варшави / Палили тут ганьбу свою, / Білизну мертвої держави; В нас три брати, то й три держави, / Той до Москви, той до Варшави, / А той до хана хабарі / Везе <... [Павличко 1, с. 522]. Способом нівелювання такої семантики $є$ однорідний ряд польських географічних назв: I дзвенять у Желязовій Волі, / В Кракові лунають і в Варшаві, / В Шльонську робітничому $і$ в Татрах <.. >; < ..> Сіяє подвиг трудовий / У Кракові й Варшаві [Рильський, с. 268].

Загалом же провідною для топоніма Варшава функцією в українському поетичному дискурсі є традиційна для узусу локативна функція. Актуалізовані ним просторові знання зосереджено передусім в історично-подієвій площині, що зумовлене, на наш погляд, територіальною близькістю та політичною значущістю Польщі для України, спільним минулим обох країн. Зокрема, таке значення аналізованої власної назви, як «місце страти», спричинене подіями XVI-XVII століть, коли на українських землях активізувався повстанський рух, тривали козацькі війни: I святі кістки біліли / Спалених в Варшаві <...> [Афанасьєв-Чужбинський, с. 35]; Край Варшави два стовпи, / На стовпах дилина, / Під стовпами молодий / Козак з Чигирина. / I найстаршї̈ пани / Смерть йому читають. / Прочитали - $і$ кати / Мотуз натягають [Руданський 1, с. 180]; Це я [чорт] також, під'юдивши Варшаву, / Посадовив на пакіл Павлюка [Славутич, с. 322]; За ті пісні, щзо їх вона складала, / за те страждання, що вона страждала, / за батька [Гордія Чурая - Ю.Б.], що розп'ятий у Варшаві, / а не схилив пред ворогом чола, - / не вистачало б городу / Полтаві, / щоб і вона ще страчена була! [Костенко 3, с. 112]; Тішить нервоньки Вариава? / Залива свинеиь за шкіру? / Гине Гуня? Наша слава! / Наливайко? То ж за віру?! [Бердник, c. 345]. Розглядане значення ойконіма може трансформуватися в інше - «місце загибелі», коли йдеться про Другу світову війну: Три козаки ридали над старою / I не могли зійти з кривавих рам. / Той під Берліном, той в сніжнім завою / Десь під Варшавою, а третій ніби сам / Од чорної наруги в тридиять сьомім [Драч, с. 115]; <..> можливо б, сьогодні щезла / Не одна з твого лоба 
столиця.... / ...коли б зачепилівські хлопиі / Не лягли тоді нагло навзнак / Під Варшавою, на Сапун-горі, / Вздовж Ельби і під Берліном [Олійник, с. 60]. Таке подієве тло, марковане зазвичай кількома топонімами, актуалізує й локативно-директивну або локативно-статичну семантику (3 Варшави, з Берліна і до Карпат / Прощання стоятиме днів на сорок. / Состави теплушок помчаться в даль, / На Дніпр і на Волгу повернуть коні; Кров. Барикади. Варшава. Повстання / <..> / Темні жандарми, орда безіменна ${ }^{1}$ [Пахльовська, с. 153]); хрематонімне значення - медаль «За визволення Варшави» (I войнську подяку / 3 них має не один. / За Будапешт, Варшаву, / Софію і Берлін [Нагнибіда, с. 217]). Зафіксовано й рух топоніма Варшава в апелятивну зону: Руїни Варшав $і$ Парижів, / Дахау й глухі Моабіти... / Кричало це все: «Ми не квити!» - / За те, що в тім пеклі ти вижив <... [Муратов, с. 221].

Аналіз українських поетичних текстів загалом засвідчує, що власна назва Варшава $є$ актуалізатором значного масиву інформації, яка стосується воєнної тематики. Локативно-директивна семантика ойконіма часто відображає напрям руху однієї зі сторін конфлікту під час таких подій:

- походи руських князів: Олеги, Ігорі, Мстислави, Брячислави! / Чи то ж ви спали, як земля тряслась / І Древня Русь до Вісли й до Варшави, / Мов бурний дух руїнний, пронеслась? [Куліш 1, с. 423];

- козацькі походи: А КОЛИ МИ ВИРУШАЛИ, / не було нам стриму, / до Молдови, до Варшави / чи ізнов до Криму, <...> / Кажу: - Пані гетьманова, / ти ж мені дивися! [Костенко 1, с. 66];

- польсько-турецька війна 1672-1676 рр.: A пан-гетьман Дорошенко / Настовборщив брови. / Наміряється пан-гетьман / Ляха воювати <...> / Пише нам вельможсий гетьман / У полки листи: / «Пійдем спершу до Києва, / А там й у Варшаву. / Братиі рідні! Загинемо, / Та добудем славу!» [Корсун, с. 314];

- Велика Північна війна, зокрема події 1701 р.: I Карло як лев могучий / Ha берег ступає, / Вісім тисяч коло Нарви / Трупом покладає. / <..> В опівночі ляцьке військо / Відігнав від Риги; / До Варшави і Клісова / Прибув ще до рання <...> / А з Варшави аж до Сасів / Прибув на вечеру <..> [Руданський 3, с. 153];

- Листопадове повстання 1830-1831 рр.: Як останній раз ляхи / Повстали за славу / I уперті москалі / Пішли на Варшаву, / Ксьондз казання говорив <...> [Руданський 3, с. 105];

- радянсько-польська війна 1919-1920 рр.: I до далекої Варшави, / 3 вогнями Києва в очах, / Поривно йдуть залізні лави, / Панам несуть червоний жах [Еллан-Блакитний, с. 83].

\footnotetext{
1 Вочевидь, мовиться про Варшавське повстання 1944 p.
} 
Маркування ойконімом Варшава чужого простору увиразнює другий складник бінарної опозиції. Усупереч очікуванням ним $є$ не корелятивний ойконім Київ, а хоронім Украӥна. На наш погляд, це зумовлене секторальним поетичним осмисленням концептуальної універсалії «свій - чужий» як «український - неукраїнський», пор.: Так чого-ж нам з Украӥни / Iти у Варшаву? [Руданський 2, с. 82]; Ми не хочем твої Волги, / Ні Варшави чи Москви, / Тільки геть із України, / В свої нетра проч іди [ЗВУ, с. 44]; Малюнки Никифора, гравюри Геиа / Експонуються у Варшаві. / Коли б иі шедеври / Повернулися в Украӥну, / Як би їм пораділи / Люди, сонце, роса, / I журавлі, звичайно, й калина, - / Рідна земля! [Лубківський, с. 139].

Виконання локативної функції подеколи пов'язане з маркуванням онімом Варшава відстані:

- далекої: - Чи Київ ще далеко? - Та не дуже. / Варшава далі, -усміхнувся дяк [Костенко 3, с. 119], пор. в українському прислів ї: Ой далеко-далеко до города Київа, а з Київа аж до Полтави, а з Полтави аж до Вариави;

- близької: Найкращий пам'ятник на світі / С під Варшавою, в селі <...> [Дмитерко, с. 226].

Декодування історичних фонових знань досліджуваного топоніма може бути утруднене для сучасного українського читача, інокультурність такої назви подеколи спричинює нерозуміння тексту й потребує вивчення додаткових джерел інформації. Наприклад, рядки з твору П. Гулака-Артемовського «IX ода Горація, книга II» «Та вже й натикали в Варшаві ви добра! / Ям!.. паль!.. рівків!.. тинків!.. шпичок $і$ частоколу!. / А як гукнув москаль по-своєму: «Гура!» - / Все к гаспиду пішло!..» [Гулак-Артемовський, с. 68] відсилають до подій Листопадового повстання: укріплення у Варшаві було зведено влітку 1831 року для оборони міста від російських військ. В уривку з поеми Юрія Клена «Попіл імперій» «Та надвоє Німеччина / давно розтята коридором; / розщив він край, як борозна, / $і$ сполучив Вариаву з морем» [Клен, с. 246] ідеться про повоєнну історію міста Гданська (Данцига), який згідно з рішенням Ялтинської конференції 1945 року втратив німецьку юрисдикцію й став частиною Польської Народної Республіки. Ретроспективного аналізу потребує й установлення історичного контексту в рядках М. Самійленка «Загомоніла Варшава!.. / Спрагла, сягниста віро! / В зграї кремлівській-шарварок... / Доля їй ще відміряє!» (27.11.1980) «Раптом - ось - думаю не як завжди: / Хай тільки серием, хай зоддалік - / Слухаю Радом, Варшаву, Забже!..» («Ніч 13/XII-1981 р.») [Caмійленко, с. 129], ключем до розуміння якого стають дати написання поезій: восени 1980 року тривали активні виступи незалежного громадського руху на чолі з Лехом Валенсою, а вночі 13.12.1981 р. в Польській Народній Республіці було запроваджено воєнний стан. 
Що ж до екстралінгвальної інформації, пов'язаної з долями співвітчизників, національною історією, то її українському читачу декодувати значно легше, тому що вона пов'язана з ментально питомим, тобто потенційно відомішим. Це, наприклад, асоціативна паралель Варшава - еміграчія: Лежимо в Варшаві, сидимо в Парижі, / Коле нам в печіниі, в животі нам ріже. / I за десять років бачим результати: / Далі все і далі від своєїхати [Олесь, с. 855]; 3 Колими, Норильська, Воркути, / з австралійських пустирів, з Варшави, / Мюнхена, Оттави - люд простий / з'їхався - Вкраӥну воскрешає [Самійленко, с. 262].

Часовою парадигмою (минуле - сучасне) спричинена поетична сакралізація власної назви Варшава, цей процес відбувається через установлення топонімно-теонімної кореляції: Переїздив я через вільну Віслу, / Що страдниці Варшаві обмиває / Криваві рани; Забулась кривава неслава, / Гірким не вернутись літам, / I руку воскресла Варшава / Радянським стискає містам [Рильський, с. 74]; < ..> У мужній страднииі Вариаві / Поміг, як брат, каменярам [Нагнибіда, с. 117]; Варшаво, < .. > / Померхло давнє біблійне диво / перед дивом твого воскресення [Костенко 2, с. 54]. Зауважимо, що в рецепції Л. Костенко топонім Варшава набуває й виразних антропоморфних рис, актуалізуючи значення «жінка»: Варшаво, / я знала, щзо ти вродлива. / Варшаво, / я чула, щзо ти пісенна. / < . .> вже й тіло були розклювали круки, / < . .> / Ще біль не пройшов. / Ще руїни - як шрами. / Але на обличчі - веселий спокій... [Костенко 2, с. 54].

Ойконім Варшава в поетичному тексті стає ключем до декодування не лише фонових знань, але й важливої особисто для ліричного героя / автора інформації, яку адресат сприймає крізь призму безпосереднього досвіду, спогадів, оцінок адресанта: Згадаєте колись, як у Варшаві / Я Вам писав оці рядочки жваві, / Згадаєте самотнього співия <...> [Вороний, с. 116]; Ніхто не стрів, ніхто не викликав / В уяві спраглій вимріяний образ. / Лиш паротяг недужо клекотав, / Гула Варшава, чорна і недобра [Маланюк 1, с. 154]; О, як вона спрагло мене втаниювала - / Вся квітувала у шалі сукні («На Маланки у Варшаві») [Драч, с. 567]; Кіно пройшло на ура! I на подив! / I скільки вигадливих епізодів! / Пригадуєш - універ, шал юрби? / А філармонію? А Варшаву? / Ми не осоромили нашу державу / в очах Отия! Янголи били лоби! [Неборак, с. 157].

Конструювання топосу польської столиці, позначеної онімом Варшава, в українському поетичному дискурсі фрагментарне, уривчасте. Здійснивши узагальнений аналіз художнього матеріалу, наведемо такі елементи її урбанопростору: Саксонський парк (Над парком Саксонським кудлачиться тінь $<\ldots>$ [Клен, с. 250]); Лазєнки (< ..> в диких Лазєнках / сновидіння < ..> [Римарук, с. 231]); костьол Анни (У Варшаві на костьолі Анни / В нішах вікон - гнізда голубів [Дмитерко, с. 224]); церква, де поховане серце Шопена ${ }^{2}(C$ цер-

\footnotetext{
2 Базиліка Святого Хреста.
} 
ква у Варшаві. Там стіна / Ховає Польщі й людськості святиню - / Шопена серие [Рильський, с. 182]); Сталінський будинок ${ }^{3}$ (У Варшаві / На Сталінському будинку / Ясен сокіл гніздо собі звив / <...> / У Вариаві / На Сталінському дарунку полякам / Сталінські очі в сокола / Сталінський дзьоб / Пильнує за Польщею <...> [Драч, с. 775]); пам'ятники Міцкевичу (Отут, над Віслою, в Варшаві, / Як над Невою й над Дніпром, / Стоять, пом'януті добром, <...> Три генії з ясним чолом («Біля пам'ятника Міцкевичу») [Дмитерко, с. 227]) та Шевченкові (І стойть Шевченко у Варшаві, / на майдані, / $і$ тримає свіч$\kappa y<\ldots>$ [Павличко 1, с. 361]); вул. Алея Шуха, $7^{4}$ (- Заглянь колись до мене на алею Шуха, 7 < ..> [Павличко 1, с. 362]); старі площі (Плинуть хмарки, наче білі пави, / Над старими площами Варшави <...> [Рильський, с. 172]); нові кам'яниці (Була - як поле, камінням засіяне. / Вродило поле нові кам'яниці [Костенко 2, с. 54]); брама (Чому ж Ви там, за брамою Варшави, / Чий брук співа під кроком ніжних ніг? [Маланюк 2, с. 80]).

Художній простір моделює й ойконімно-гідронімна пара Варшава - Вісла. Такий спосіб репрезентації фонових знань топонімів $€$ досить продуктивним у поетичному дискурсі, пор., наприклад, в І. Римарука: Вечоріє Варшава, темніє, мов срібний перстеник, / і блідніє, сріблішає, світиться біла рука. / Ти шукав цього світла - здавен, по шляхах неблизеньких. / Наздогнав його там, біля Вісли; Від Києва твої дощі / у потойбічному керунку / ідуть, мов арії в Тібет. / < ... / Ще споглядає віщиий кущ, / як рвуться дощові ворізки / по той бік Лети і Дніпра [Римарук, с. 231].

Частими контекстуальними актуалізаторами історичної або культурної інформації топоніма Варшава стають антропоніми як рефлексація фактів біографії осіб, які безспосередньо чи опосередковано стосуються польської столиці, чи фактів посмертного їх вшанування, наприклад: Довго таке робилося, / Поки не в Варшаві / Запановав над ляхами / Понятовський жвавий [Шевченко, с. 135]; Куліш Пантелеймон служив царю, / полякам у Варшаві правив мову < ...> [Неборак, с. 66]; < ..> тістка найліпші в кав'ярнях Ларделлі <..> / вітер веселий гуде по Варшаві [Клен, с. 250]; Варшаво <..> / вже й серие Шопена украв твій ворог [Костенко 2, с. 54]. Подеколи до встановлення такого зв’язку залучено паратекстові елементи - заголовок («Мазепа): Тaк ось він, Київ, щуо йому / В Варшаві снився і в Криму [Сосюра, с. 135]; «Посмертна маска Міцкевича»: Але найліпше тобі / У Кракові та Варшаві, / У Львові - теж незле... [Лубківський, с. 495]) або епіграф (<...> На репетицію мчиш до Вариави... («Журавлі». Ярославові Полянському, керівникові українського народного хору «Журавлі» в Польській Народній Республічі [Драч, с. 513]).

\footnotetext{
3 Палац культури і науки, найвищий хмарочос у Польщі.

4 За цією адресою розташоване Посольство України в Республіці Польща.
} 
Отже, моделювання лінгвопоетичного коду топоніма Варшава як репрезентанта чужого простору в українському дискурсі зосереджене передусім в історичній площині. Письменники актуалізують насамперед ту екстралінгвальну інформацію, що стосується мілітарної тематики. Продуктивними $є$ надання аналізованій власній назві ознак хороніма з одночасною актуалізацією таких значень, як «імперськість», «поневоленість» або «європейськість», застосування онімної взаємодії (топонімно-топонімної, топонімно-антропонімної). Обмежено реалізовано фоновий потенціал ойконіма, пов’язаний із семантикою столиці, топосом міста. Загалом потверджуючи факт периферійності оніма Варшава в українській мовнопоетичній картині світу, зазначимо, що його інформаційне поле має асиметричний вияв із домінуванням історичного та помітністю соціокультурного сегмента.

\section{СПИСОК СКОРОЧЕНЬ}

\section{Джерела}

Афанасьєв-Чужбинський - АФАНАСьєв-Чужьинський Олександр, 1972, Поезї̈ Радянський письменник, Київ/AfANASIEv-ChUZнBYNSKY Oleksandr, 1972 , Poezii, Radianskyi pysmennyk, Kyiv.

Бабій - БАБІй Олесь, 1956, Повстаниі, Літературне видавництво, Чікаго/ВАвІІ Oles, 1956, Povstanci, Literaturne vydavnyctvo, Chikago.

Бердник - БЕрдник Олесь, 2008, Золоті ворота, Смолоскип, Київ/BERDNYк Oles, 2008, Zoloti vorota, Smoloskyp, Kyiv.

Вороний - Вороний Микола, 1996, Поезії. Переклади. Критика. Публіиистика, Наукова думка, Київ/Vorony Mykola, 1996, Poezii. Pereklady. Krytyka. Publicystyka, Naukova dumka, Kyiv.

Гулак-Артемовський - ГуЛАК-АРтЕмовський Петро, 1984, Поетичні твоpu, Наукова думка, Київ/Hulak-Artemovsкy Petro, 1984, Poetychni tvory, Naukova Dumka, Kyiv.

Дмитерко - Дмитерко Любомир, 1981, Твори в 4 m., т. 1, Дніпро, Київ/ DMYterko Liubomyr, 1981, Tvory $v 4$ t., t. 1, Dnipro, Kyiv.

Драч - Драч Іван, 2007, Берло, Грамота, Київ/Drach Ivan, 2007, Berlo, Hramota, Kyiv.

Еллан-Блакитний - ЕллАн-БлАКитний Василь, 1964, Поезї, Радянський письменник, Київ/Ellan-BlaкyтnYi Vasyl, 1964, Poezii, Radianskyi pysmennyk, Kyiv.

Жадан - ЖАдАн Сергій, 2006, Цитатник, Фоліо, Харків/ZhaDAn Sergii, 2006, Cytatnyk, Folio, Charkiv. 
ЗВУ - Гıщинський Євген, упоряд., 2007, За волю України, антологія пісень національно-визвольних змагань, Волинська книга, Луцьк/НISHCHYNSKYI Yevhen, uporiad., 2007, Za voliu Ukrainy, antolohiia pisen nacionalno-vyzvolnykh zmahan, Volynska knyha, Łuck.

ІП - Дей Олексій, упоряд., 1963, Ігри та пісні. Весняно-літня поезія трудового року, Видавництво Академії наук Української РСР, Київ/DeI Oleksii, uporiad., 1963, Ihry ta pisni. Vesniano-litnia poeziia trudovoho roku, Vydavnyctvo Akademii nauk Ukrainskoi RSR, Kyiv.

КОП - ЧЕБАНЮК Олена, упоряд., 1987, Календарно-обрядові пісні, Дніпро, Київ/Сheваniuк Olena, uporiad., 1987, Kalendarno-obriadovi pisni, Dnipro, Kyiv.

Клен - Клен Юрій, 1991, Вибране, Дніпро, Київ/KLEN Yurii, 1991, Vybrane, Dnipro, Kyiv.

Корсун - Корсун Олександр, 1987, Дорошенко, в: Українські поети-романтики, Наукова думка, Київ/KoRSUn Oleksandr, 1987, Doroshenko, v: Ukrainski poety-romantyky, Naukova Dumka, Kyiv.

Костенко 1 - Костенко Ліна, 2010, Берестечко, Либідь, Київ/Kostenкo Lina, 2010, Berestechko, Lybid, Kyiv.

Костенко 2 - Костенко Ліна, 1961, Мандрівки серия, Радянський письменник, Київ/Kostenкo Lina, 1961, Mandrivky sercia, Radianskyi pysmennyk, Kyiv.

Костенко 3 - Костенко Ліна, 1979, Маруся Чурай, Радянський письменник, Київ/Kostenko Lina, 1979, Marusia Churai, Radianskyi pysmennyk, Kyiv.

Куліш 1 - Кулгш Пантелеймон, 1994, Твори в 2 m., т. 1, Наукова думка, Київ/ Kulish Panteleimon, 1994, Tvory v 2 t., t. 1, Naukova Dumka, Kyiv.

Куліш 2 - Кулाш Пантелеймон, 1994, Твори в 2 m., т. 2, Наукова думка, Київ/ Kulish Panteleimon, 1994, Tvory v 2 t., t. 2, Naukova Dumka, Kyiv.

Лубківський - Луьківський Роман, 2006, Громове дерево, Український письменник, Київ/LubKIVSKYı Roman, 2006, Hromove derevo, Ukrainskyi pysmennyk, Kyiv.

Маланюк 1 - МАлАнюк Євген, 1992, Поезї̈, УПІ ім. І. Федорова, Фенікс Лтд., Львів/Malaniuk Yevhen, 1992, Poezii, UPI im. I. Fedorova, Feniks Ltd., Lviv. Маланюк 2 - МАлАнюк Свген, 2001, Невичерпальність, Веселка, Київ/ MalaniuK Yevhen, 2001, Nevycherpalnist, Veselka, Kyiv.

Масенко - МАсенко Терень, 1975, Вибране, Дніпро, Київ/MaSEnko Teren, 1975, Vybrane, Dnipro, Kyiv.

Муратов - Муратов Ігор, 1980, Поезї, Радянський письменник, Київ/Muratov Igor, 1980, Poezii, Radianskyi pysmennyk, Kyiv.

Нагнибіда - НАгнибідА Микола, 1971, Вибране, т. 1, Дніпро, Київ/NAHNYвIDA Mykola, 1971, Vybrane, t. 1, Dnipro, Kyiv. 
Неборак - НЕБорАк Віктор, 2013, Літаюча голова, А-БА-БА-ГА-ЛА-МА-ГА, Київ/NeBORAK Viktor, 2013, Litaiucha holova, A-BA-BA-HA-LA-MA-HA, Kyiv.

Олесь - Олесь Олександр, 1990, Твори у 2 m., т. 1, Дніпро, Київ/OLes Oleksandr, 1990, Tvory u 2 t., t. 1, Dnipro, Kyiv.

Олійник - Олгйник Борис, 2005, Основи, Дніпро, Київ/OLIINyк Borys, 2005, Osnovy, Dnipro, Kyiv.

Павличко 1 - ПАвличко Дмитро, 2008, Вибрані твори, т. 1, Українська енциклопедія ім. М.П. Бажана, Київ/PAVLYCHко Dmytro, 2008, Vybrani tvory, t. 1, Ukrainska encyklopediia im. M.P. Bazhana, Kyiv.

Павличко 2 - ПАвличко Дмитро, 2014, Вірші з Майдану, Основи, Київ/ Pavlychko Dmytro, 2014, Virshi z Maidanu, Osnovy, Kyiv.

Павличко 3 - ПАвличко Дмитро, 1998, Ностальгія, Основи, Київ/РАVLYснко Dmytro, 1998, Nostalhiia, Osnovy, Kyiv.

Павличко 4 - ПАвличко Дмитро, 1989, Твори у 3 m., т. 2, Дніпро, Київ/ PavlychKo Dmytro, 1989, Tvory u 3 t., t. 2, Dnipro, Kyiv.

Пахльовська - ПАхльовськА Оксана, 1988, Долина Храмів, Радянський письменник, Київ/PAкHLOvsка Oksana, 1988, Dolyna Khramiv, Radianskyi pysmennyk, Kyiv.

Рильський - Рильський Максим, 1984, Зібрання творів у 20 m., т. 4, Наукова думка, Київ/RYLSKYı Maksym, 1984, Zibrannia tvoriv u 20 t., t. 4, Naukova Dumka, Kyiv.

Римарук - РимАРук Ігор, 2017, Три потоки місячного світла, А-БА-БА-ГАЛА-МА-ГА, Київ/RYмARUк Ihor, 2017, Try potoky misiachnoho svitla, A-BABA-HA-LA-MA-HA, Kyiv.

Руданський 1 - РудАнський Степан, 1985, Співомовки. Переклади та переспіви, Наукова думка, Київ/RUdANSKy Stepan, 1985, Spivomovky. Pereklady ta perespivy, Naukova Dumka, Kyiv.

Руданський 2 - Твори Степана Руданського, 1913, т. 2, накладом т-ва «Просвіта», Львів/Tvory Stepana Rudanskoho, 1913, t. 2, nakładom t-va „Prosvita”, Lviv.

Руданський 3 - РудАнський Степан, 2007, Усі твори в одному томі, ВТФ «Перун», Київ, Ірпінь/RUdANSKy Stepan, 2007, Usi tvory v odnomu tomi, VTF «Perun», Kyiv, Irpin.

Самійленко - САмійленко Микола, 1995, Яса, Український письменник, Київ/ SAmillenko Mykola, 1995, Yasa, Ukrainskyi pysmennyk, Kyiv.

Славутич - СлАвутич Яр, 1978, Зібрання творів 1938-1978, Славута, Едмонтон/Slavutych Yar, 1978, Zibrannia tvoriv 1938-1978, Slavuta, Edmonton.

Сосюра - СосюрА Володимир, 2000, Вибрані твори у 2 m., т. 2, Наукова думка, Київ/Sosiura Volodymyr, 2000, Vybrani tvory u 2 t., t. 2, Naukova dumka, Kyiv. 
СПП - ХмІлЕвсьКА О., упоряд., 1985, Соціально-побутові nicнi, Дніпро, Київ/ Khmilevska O., uporiad., 1985, Socialno-pobutovi pisni, Dnipro, Kyiv.

УНДІП - ПАвЛІй П., РодІнА М., СтеЛьмах М., УПоряд., 1955, Украӥнські народні думи та історичні пісні, Видавництво Академії наук Української РСР, Київ/Pavli P., Rodina M., Stelmakn M., uporiad., Ukrainski narodni dumy ta istorychni pisni, Vydavnyctvo Akademii nauk Ukrainskoi RSR, Kyiv.

Українка - УкрАїнкА Леся, 2008, Усі твори в одному томі, Перун, Київ/ Ukrainka Lesia, 2008, Usi tvory v odnomu tomi, Perun, Kyiv.

Усенко - УСенко Павло, 1972, Твори у 2 m., т. 1, Дніпро, Київ/Usenko Pavlo, 1972, Tvory u 2 t., t. 1, Dnipro, Kyiv.

Шевченко - Шевченко Тарас, 2003, Зібрання творів у 6 m., т. 1, Наукова думка, Київ/SHevchenko Taras, 2003, Zibrannia tvoriv u 6 t., t. 1, Naukova dumka, Kyiv.

\section{БІБЛІОГРАФІЯ}

Данилюк Ніна О., 2011, Топоніми на позначення іноземних локусів у текстах народних пісень, в: Науковий вісник Волинського начіонального університету ім. Лесі Украӥнки. Серія «Філологічні науки: Мовознавство», № 5, ч. 2, c. 30-35/DANYLIUK Nina O., 2011, Toponimy na poznachennia inozemnykh lokusiv u tekstakh narodnykh pisen, v: Naukowyi visnyk Volynskoho nacionalnoho universytetu im. Lesi Ukraiinky. Seriia «Filolohichni nauky: Movoznavstvo», № 5, ch. 2, s. 30-35.

Доценко Марія В., 2016, Зв'язок топонімікону і жанрово-стильової природи тексту, в: Науковий вісник Міжнародного гуманітарного університету: Серія «Філологія» № 20(1), с. 20-22/Docenко Mariia V., 2016, Zviazok toponimikonu i zhanrovo-stylovoi pryrody tekstu, v: Naukovyi visnyk Mizhnarodnoho humanitarnoho universytetu: Seriia «Filolohiia», № 20(1), s. 20-22.

Дуьина Наталія М., 2000, Функиії топонімів у веснянках, в: Записки з ономастики, вип. 4, с. 47-54, http://karpenko.in.ua/wp-content/uploads/20 13/02/Dubina4.pdf (дата звернення: 22.03.2021)/DuBYNA Nataliia M., 2000, Funkcii toponimiv u vesniankakh, v: Zapysky z onomastyky, vyp. 4, s. 47-54, http://karpenko.in.ua/wp-content/uploads/2013/02/Dubina4.pdf (data zvernennia: 22.03.2021).

Корнієнко Ірина, СФІмовська Оксана, 2016, Поетоніми як стилістичні засоби в історичному романі Ліни Костенко «Маруся Чурай», в: Науковий вісник Миколаївського національного університету ім. В. О. Сухомлинського: Серія «Філологічні науки», № 2, с. 136-139/Kornitenko Iryna, YeFImovsкA 
Oksana, 2016, Poetonimy yak stylistychni zasoby $v$ istorychnomu romani Liny Kostenko «Marusia Churai», v: Naukovyi visnyk Mykolaiivskoho nacionalnoho universytetu im. V.O. Sukhomlynskoho: Seriia «Filolohichni nauky», № 2, s. $136-139$.

ЛАРИнА Татьяна И., 2014, Украина в фокусе, или топонимические тропы в СМИ (на материале англо-, русско- и польскоязычной прессы), в: Русский язык: система и функиионирование (к 75-летию филологического факультета): сб. материалов VI Междунар. науч. конф., Минск, 28-29 октября 2014 г., ч. 2, Изд. центр БГУ, Минск, с. 234-239, https://elib.bsu.by/handle/123456789 /110335 (дата звернення: 2.02.2021)/LARINA Tat'yana I., 2014, Ukraina $v$ fokuse, ili toponimicheskie tropy $v$ SMI (na materiale anglo-, russko$i$ pol'skoyazychnoj pressy), v: Russkij yazyk: sistema i funkcionirovanie (k 75-letiyu filologicheskogo fakul'teta): sb. materialov VI Mezhdunar. nauch. konf.), Minsk, 28-29 oktiabria 2014 g., ch. 2, Uzd. Centr BGU, Minsk, s. 234-239, https://elib.bsu.by/handle/123456789/110335 (data zvernennia: 2.02.2021).

ЛЕйьов Роман, 2012, Русская слава и польская столица: к истории одного рифменного клише, в: История литературы. Поэтика. Кино: Сборник в честь Мариэтты Омаровны Чудаковой, Новое издательство, Москва, c. 187-198/LeJBov Roman, 2012, Russkaya slava i pol skaya stolica: $k$ istorii odnogo rifmennogo klishe, v: Istoriya literatury. Poetika. Kino: Sbornik v chest' Marietty Omarovny Chudakovoj, Novoie izdatel'stvo, Moskva, s. 187-198.

Мельник Мирослава Р., 1999, Ономастика творів Ліни Костенко, автореф. дис. канд. філол. наук, Одеса/Melnyк Myroslava R., Onomastyka tvoriv Liny Kostenko, avtoref. dys. kand. filol. nauk, Odesa.

Милькевич Елена С., 2017, Применение когнитивных приниипов к описанию метонимии (на примере английских заголовков статей), «Известия Южного федерального университета. Филологические науки», № 2, с. 144-152/ MiL'Kevich Elena S., 2017, Primenenie kognitivnyh principov $k$ opisaniyu metonimii (na primere angliiskih zagolovkov statej), «Izvestiya Yuzhnogo federal'nogo universiteta. Filologicheskie nauki», № 2, s. 144-152.

МожАРова Тамара, 2008, Головні тенденції використання топонімів у поетичному мовленні та їхні стилістичні функиії (на матеріалі поезій I. Драча), в: Вісник Кременчуцького державного політехнічного університету ім. Михайла Остроградського, № 5(52), ч. 2, с. 184-187/Mozharova Tamara, 2008, Holovni tendencii vykorystannia toponimiv u poetychnomu movlenni ta yikhni stylistychni funkcii (na materiali poezii I. Dracha), v: Visnyk Kremenchuckoho derzhavnoho politekhnichnoho universytetu im. Mykhaila Ostrohradskoho, № 5(52), ch. 2, s. 184-187.

Мороз Оксана А., 2011, Топоніми в украӥнській мові: когнітивний, прагматичний, конотативний аспекти, в: Вісник Маріупольського державного 
університету: Серія «Філологія», вип. 5, с. 45-51/Moroz Oksana А., 2011, Toponimy v ukrainskii movi: kohnityvnyi, prahmatychnyi, konotatyvnyi aspekty, v: Visnyk Mariupolskoho derzhavnoho universytetu: Seriia «Filolohiia», vyp. 5, s. $45-51$.

Тєлєжкіна Олеся О., 2012, Топопоетоніми в художньому просторі Дмитра Павличка, в: Вісник Запорізького національного університету: Серія «Філологічні науки» № 1, с. 431-436/TIELIEZHKina Olesia O., 2012, Topopoetonimy v khudozhnomu prostori Dmytra Pavlychka, v: Visnyk Zaporizkoho nacionalnoho universytetu: Seriia «Filolohichni nauky», № 1, s. 431-436.

Торчинський Михайло М., 2009, Структура онімного простору української мови, ч. II: Функиіонування власних назв, ХНУ, Хмельницький/ТoRCHYNSKYI Mykhailo M., 2009, Struktura onimnoho prostoru ukrainskoi movy, ch. II: Funkcionuvannia vlasnykh nazv, KHNU, Khmelnyckyi.

Франко Іван, 1910, Студї̈ над українськими народнїми піснями, в: Записки Наукового товариства ім. Шевченка, вип. XCIV, с. 48-53/Franko Ivan, 1910, Studii nad ukrainskymy narodnymy pisniamy, v: Zapysky Naukovoho tovarystva im. Shevchenka, vyp. XCIV, s. 48-53.

SzelążeK Wacław, 1918, Warszawa w poezji polskiej, Wydawnictwo M. Arcta, Warszawa.

\section{Streszczenie \\ KSZTAŁTOWANIE JĘZYKOWO-POETYCKIEGO KODU TOPONIMU WARSZAWA W DYSKURSIE UKRAIŃSKIM}

Slowa kluczowe: dyskurs poetycki, onim, toponim, ojkonim, choronim, Warszawa

W artykule przedstawiono wyniki analizy językowo-poetyckiego kodu toponimu Warszawa, który reprezentuje „obcą” kulturę w dyskursie ukraińskim w XVIII-XXI wieku. Ustalono, że kształtowanie takiego kodu koncentruje się przede wszystkim na płaszczyźnie wydarzeń historycznych. Autor stwierdza, że wynika to z bliskości terytorialnej oraz wspólnej przeszłości obu krajów, a także z politycznego znaczenia Polski dla Ukrainy. Pisarze najczęściej aktualizują tę ekstralingwistyczną informację, która dotyczy tematyki wojskowej. Produktywne jest nadanie analizowanej nazwie własnej cech choronimu przy jednoczesnej aktualizacji takich znaczeń, jak 'imperializm', 'niewolnictwo' czy 'europejskość', zastosowanie interakcji onimicznej (toponimiczno-toponimicznej, toponimiczno-antroponimicznej). Znaczenie 'stolica' uwypuklają kontekstowe leksemy państwowość, państwo, ojkonimiczno-choronimiczna para Warszawa-Rzeczpospolita. Toponim Warszawa to także wyznacznik przestrzeni „obcej” w odpowiedniej opozycji binarnej, wówczas gdy wyznacznikiem „swojej” przestrzeni staje się, wbrew oczekiwaniom, nie korelacyjny ojkonim Kijów, lecz choronim Ukraina. Nie w pełni realizowano potencjał tła ojkonimu związany z semantyką stolicy, toposem miasta. Poprzez ustalenie toponimiczno-teonimicznej korelacji odbywa się poetycka sakralizacja analizowanego onimu. Zasadniczo pole informacyjne nazwy własnej Warszawa w ukraińskim dyskursie poetyckim przejawia się asymetrycznie, z przewagą segmentu historycznego i zauważalną obecnością segmentu społeczno-kulturowego. 